\title{
Nitrogen Removal from Groundwater Using a Swim-bed Biological Reactor
}

\author{
DOAN THU HA', RYUICHI KANDA², TOHICHIROU KOYAMA ${ }^{3}$, and KENJI FURUKAWA ${ }^{2}$ \\ ${ }^{1}$ Graduate School of Science and Technology, Kumamoto University \\ /2-39-1 Kurokami, Kumamoto 860-8555, Japan \\ ${ }^{2}$ Department of Civil Engineering and Architecture, Faculty of Engineering, Kumamoto Universtity \\ /2-39-1 Kurokami, Kumamoto 860-8555, Japan \\ ${ }^{3}$ NET Company Ltd.,/Kouyoh-dai Kawanishi 666-0115, Japan
}

\begin{abstract}
High nitrate concentrations in drinking water cause a potential risk to public health, especially for infants. In this study, nitrate removal process using a novel acryl resin fiber biofringe (BF) material as biomass carrier and swim-bed technology was performed in a biological denitrifying reactor (DNBF). This process combines many advantages of both fixed-bed and fluidized-bed such as a long sludge retention time, low effluent suspended solids and turbidity, reduced sensitivity to toxic loads, high treatment efficiency and no need for sludge recycle, etc. Denitrification efficiencies of $80 \sim 90 \%$ at volumetric loading rates of up to $1.44 \mathrm{~kg} / \mathrm{m}^{3} / \mathrm{d}$ were achieved in this study with the simple operation and easy maintenance of DNBF process. Clear effluent with low SS levels of less than $10 \mathrm{mg} / \mathrm{l}$ were observed in whole experimental period. Sludge yield of $0.29 \mathrm{~g} \mathrm{VSS} / \mathrm{g} \mathrm{NO}_{3}-\mathrm{N}_{\text {removed }}$ and the average sludge retention time of 44 days were approximately calculated. The adaptation in denitrification of DNBF to the change of reactor bulk DO level, stirrer speed, C/N ratio and influent $\mathrm{NO}_{3}^{-}$concentration were also investigated in this study.
\end{abstract}

Keywords: biofringe, denitrification, groundwater, nitrification, swim-bed technology

\section{INTRODUCTION}

Nitrate is considered to be relatively less toxic for adult but it can cause health problems for infants, especially those under six months of age. Nitrate can easily be converted to nitrite in the environment by bacteria. In infants, nitrate interacts with the hemoglobin in red blood cells, which causes an oxygen deficiency resulting in methemoglobinemia, commonly known as "blue baby syndrome". The Would Health Organization (WHO) has set maximal allowable concentrations of $11.3 \mathrm{mg} \mathrm{NO}{ }_{3}^{-}-\mathrm{N} / l$ and $0.03 \mathrm{mg} \mathrm{NO}_{2}^{-}-\mathrm{N} / l$ in drinking water ${ }^{1}$. Hanoi groundwater, the main source for Hanoi water supply, is presently not contaminated with nitrate (nitrate level of about $3 \mathrm{mg} / l$ ), but contaminated with ammonium at concentrations range from trace to $30 \mathrm{mg} / l$. The heavily polluted areas are located in the southern part of $\mathrm{Hanoi}^{2}$. At present, by applying the convention water treatment process of aeration, sedimentation, filtration and clorine disinfections, effectiveness of ammonium removal is very low in water treatment plants where groundwater sources containing high ammonium and iron concentrations ${ }^{2)}$. Ammonium is easily converted to nitrite and nitrate through biological nitrification process. In order to meet the WHO standard, nitrogen removal treatment must be applied. Nitrification of ammoniumcontaminated Hanoi groundwater was conducted in our previous studies, ${ }^{3,4}$. In this study, biological nitrate removal (deni- 
trification) was experimentally studied. Biological denitrification is well known as conventional nitrate removal method. Other nitrate removal methods with different cost levels and removal performances such as ion exchange, reverse osmosis, and electrodialysis can also be used for drinking water. However these methods have several disadvantages such as excessive operational costs, operational limitations, and problem associated with the waste disposal of byproducts, which can greatly reduced by the biological denitrification process ${ }^{5)}$.

Traditional nitrogen removal systems consist of aerobic nitrification by autotrophic organisms and anaerobic denitrification by heterotrophic organisms ${ }^{5}$. In the first step of nitrification, ammonium is finally oxidized via nitrite to nitrate. In the second step of denitrification, nitrate is reduced via nitrite to nitrogen gas $\mathrm{N}_{2}$. New biological processes for ammonium removal have been developed recently, in which shortcuts in the nitrification-denitrification part are used, such as the denitrification via nitrite instead of nitrate in the Sharon process ${ }^{6}$, or ammonium is oxidized anaerobically with nitrite to $\mathrm{N}_{2}$ by autotrophic bacteria in the anammox process $^{7)}$, or nitrogen removed over nitrite in the completely autotrophic as Canon process ${ }^{8)}$ and SNAP process ${ }^{9}$. These new processes have become of interest as the economical nitrogen removal methods. However all of these are applicable only for ammonium-rich wastewater treatment, but all of these new processes also have been reported as applicable process for the separated treatment of ammonium-rich wastewater. Thus, the separate nitrification and denitrification process is still considered the best method for nitrogen removal from ammonium contaminated groundwater.

In the denitrification step, under anoxic condition, nitrate is converted to harmless nitrogen gas by the following steps ${ }^{10}$ :

$$
\mathrm{NO}_{3} \rightarrow \mathrm{NO}_{2} \rightarrow \mathrm{NO} \rightarrow \mathrm{N}_{2} \mathrm{O} \rightarrow \mathrm{N}_{2}
$$

Denitrification can be accomplished by both heterotrophic and autotrophic bacteria. In heterotrophic denitrification process, nitrate as the electron acceptor and organic substrate is electron donor. Various organic substrates have been used for biological heterotrophic denitrification processes such as ethanol, methanol, acetic acid or methane, etc, of which ethanol and methanol is widely used. Many studies have been carried out to compare ethanol and methanol as carbon sources for denitrification and ethanol was found to be more effective. Savia et al. ${ }^{11)}$, Magnus et al. ${ }^{12)}$, and Sara Hallin ${ }^{13)}$ reported that efficient denitrification using ethanol was established in a short time than by using methanol. Magnus ${ }^{12)}$ and Delanghe et al. ${ }^{14)}$ also reported that denitrification with ethanol is more stable compared to that with methanol. Methanol generally selected in practice because it less expensive ${ }^{13)}$ and less sludge production, but recently its use has been questioned due to poisonous effects if ingested ${ }^{15}$.

Mateju et al. ${ }^{16)}$ reported the stoichiometric relationship of heterotrophic denitrification with ethanol $\left(\mathrm{C}_{2} \mathrm{H}_{5} \mathrm{OH}\right)$ as carbon source as given by Eq. (1)

$$
\begin{array}{r}
0.613 \mathrm{C}_{2} \mathrm{H}_{5} \mathrm{OH}+\mathrm{NO}_{3}{ }^{-} \rightarrow 0.10 \mathrm{C}_{5} \mathrm{H}_{7} \mathrm{NO}_{2}+ \\
0.7124 \mathrm{CO}_{2}+0.286 \mathrm{OH}^{-}+0.98 \mathrm{H}_{2} \mathrm{O}+0.449 \mathrm{~N}_{2}
\end{array}
$$

Where $\mathrm{C}_{5} \mathrm{H}_{7} \mathrm{O}_{2} \mathrm{~N}$ represents is biological cell formula. The substrate $\left(\mathrm{C}_{2} \mathrm{H}_{5} \mathrm{OH}\right)$ and $\mathrm{NO}_{3}{ }^{-}$ ratio $\left(\mathrm{g} \mathrm{C}_{2} \mathrm{H}_{5} \mathrm{OH} / \mathrm{g} \mathrm{NO} \mathrm{NO}_{3}^{-}\right)$is 0.455 or $\mathrm{C} / \mathrm{N}$ ratio of 1.05 and $10 \%$ of applied $\mathrm{NO}_{3}-\mathrm{N}$ is used for cell synthesis.

Heterotrophic biological denitrification has been widely studied, both at lab-laboratory and full-scale application. Different types of denitrification reactor were conducted as: suspended growth, packed or fix bed, and fluidized bed. Different support media were used as biomass carrier such as expanded schist, anthracite, and sand in fixed bed denitrification reactor, sand in fluidized bed reactor, and sodium alginate polymer in immobilized denitrification process ${ }^{17)}$. Suspended culture provided higher nitrate removal than biofilms but clarifier for solidliquid separation and biomass return is needed. Immobilized cells technology in fix bed denitrification reactor offers the advantage in high reaction rate; reduce reactor volume, stable operation without 
clarifier and biomass recycle. However there are limitations on the rate of substrate diffution and reaction products through the biomass, which result in the detachment of sludge from the biofilm and reduced cell activity $^{17}$. Clogging problem can also occurs in fix-bed denitrification reactors, thus frequent washing is requited.

In this study, swim-bed technology ${ }^{18)}$, involving the novel acryl resin fiber material of biofringe (NET Co. Ltd., BF-18) was applied for nitrogen treatment of groundwater. The biofringe material (BF) has a rough texture allowing for attachment of large amounts of biomass. The biofringe with a flexible fringe yarn matrix in a fix position induced by water flow creates a "swimming" motion that enhances mass transfer of nutrients to the attached growth biofilm. This process combines many advantages of both fix-bed and fluidized-bed attachedgrowth processes such as a long sludge retention time, low effluent suspended solids and turbidity, high treatment efficiency and no need for sludge recycle. This process can reduce sensitivity to the changes of operational conditions such as nitrogen loading rate, oxygen and temperature, etc. It also eliminates head losses with absence of clogging and channeling, which cannot be easily avoided in fix-bed processes. This process is continuously operated without medium or the requirement of screens or traps to prevent washout, which can be difficult to achieve in fluidized bed processes. Two reactors using the $\mathrm{BF}$ biomass carrier were used in this study, one for nitrification tests (named NBF) and another for denitrification tests (named DNBF). In this report, we focus on the denitrification process. Ethanol was used as organic substrate for denitrification in this study.

\section{MATERIALS AND METHODS}

Experimental system Figure 1 shows a schematic diagram and photographs of the denitrification experimental system used in this study. The main components of the experimental denitrification system consisted of the reactor, influent tank, carbon source and nutrients tanks, stirrer, and peristaltic feed pumps. The reactor used in this study was made from acryl resin and had a diameter of $210 \mathrm{~mm}$ and the height to the outlet port was $390 \mathrm{~mm}$ with a total volume of $14 l$. The reactor had two main parts, the central column of $50 \mathrm{~mm}$ in diameter and $365 \mathrm{~mm}$ in height served as a mixing zone and downdraft section. The mechanical stirrer (FBLM 575 W-A, 3000 rpm) was placed in this zone for mixing as well as providing circulation throughout the reactor. Influent and ethanol-phosphate solutions were introduced within the downdraft section of the mixing zone using peristaltic pumps. The operational temperature of the reactor was maintained at $25^{\circ} \mathrm{C}$.

The biological zone in the updraft section contained four double-yarns of BF as biomass carriers. The support filament of $325 \mathrm{~mm}$ in length contained 103 fringe yarns for each $\mathrm{BF}$ carrier. The total volume parking ratios and specific surface areas of the BF carrier were $0.69 \%$ and $12.53 \mathrm{~m}^{2} / \mathrm{m}^{3}$, respectively. A pipe of $9 \mathrm{~mm}$ in diameter connected to an air pump containing 10 holes of $0.1 \mathrm{~mm}$ in diameter was placed in the bottom of the reactor for back washing.

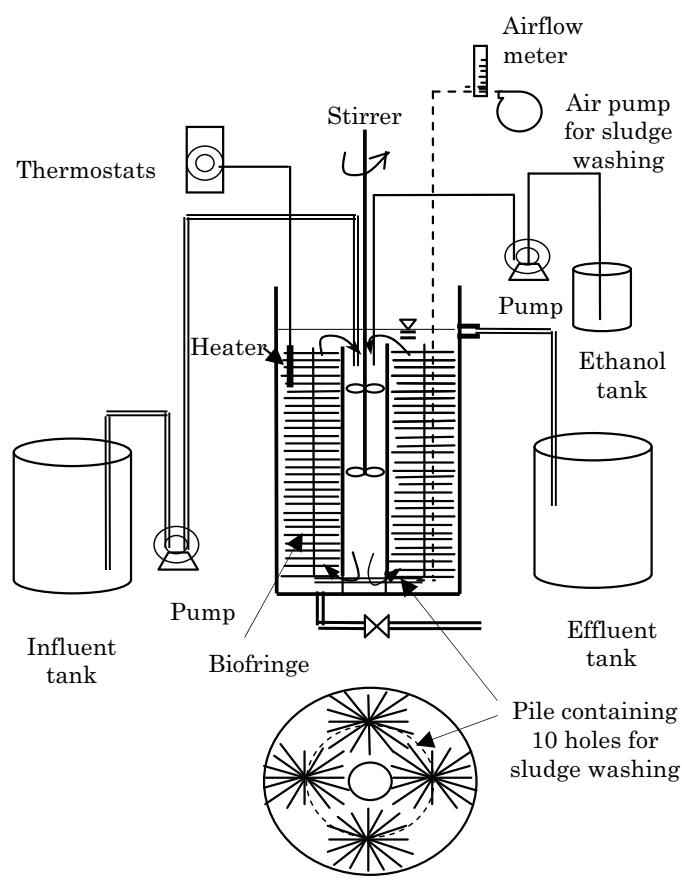

Fig. 1 Schematic diagram of the experimental system 
The DNBF reactor was initially seeded with laboratory activated sludge. This sludge had also been used for the NBF reactors, in which oxygen was supply for aerobic growth conditions. Batch denitrification tests were conducted to confirm the denitrifying activity of the seed sludge. A specific denitrification rate of $2.5 \mathrm{mg}-\mathrm{N} / \mathrm{g}-\mathrm{VSS} / \mathrm{h}$ was determined demonstrating that denitrifying biomass was present in the seed activated sludge. Figure 2 shows the photographs the $\mathrm{BF}$ material, reactor, and the DNBF reactor containing a large amount of sludge.

Experimental procedures For startup of the reactor, $28 \mathrm{~g}$ of seed activated sludge was inoculated in the DNBF reactor. Suspended solids (SS) analyses showed $98 \%$ and $100 \%$ of total sludge had attached on biofringe during 24 and 30 hours of liquid circulation, respectively. After the attachment stage of seed sludge, nitrogen removal experiments combining nitrification and denitrification were initiated. The effluent of the NBF was used as influent for a continuous-flow experiment in the DNBF, as shown in Fig. 3a (an HRT of 10 hours was kept in this period). From day 30, the combined system separated and synthetic influent containing $30 \mathrm{mg} \mathrm{NO}-\mathrm{N} / l$ was introduced for the DNBF reactor (Fig. 3b). An HRT of 10 hours was maintained for an initial $\mathrm{NO}_{3}^{-}$loading rate of a)

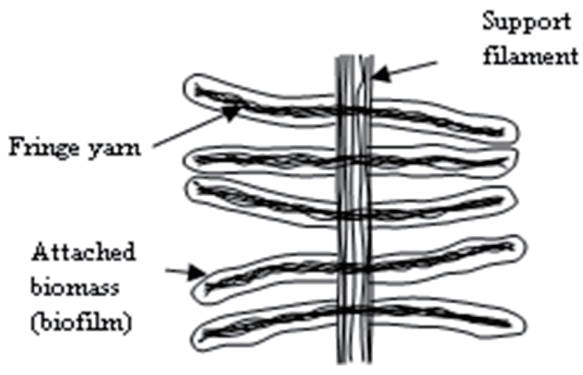

b)

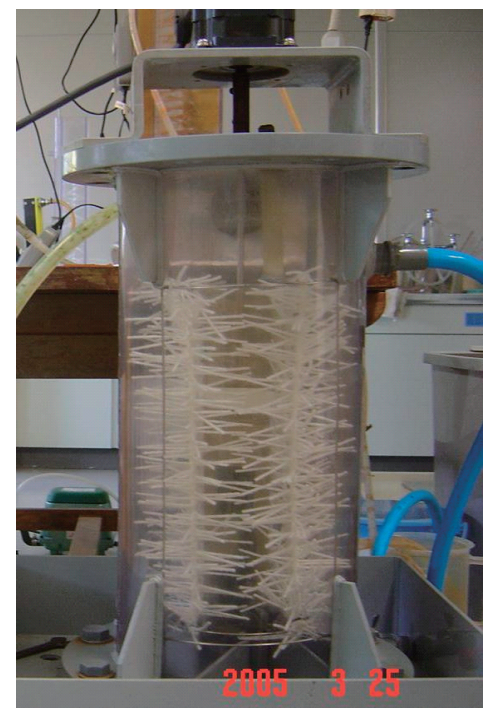

Fig. 2 Photographs of BF material and reactor during experiment

a)

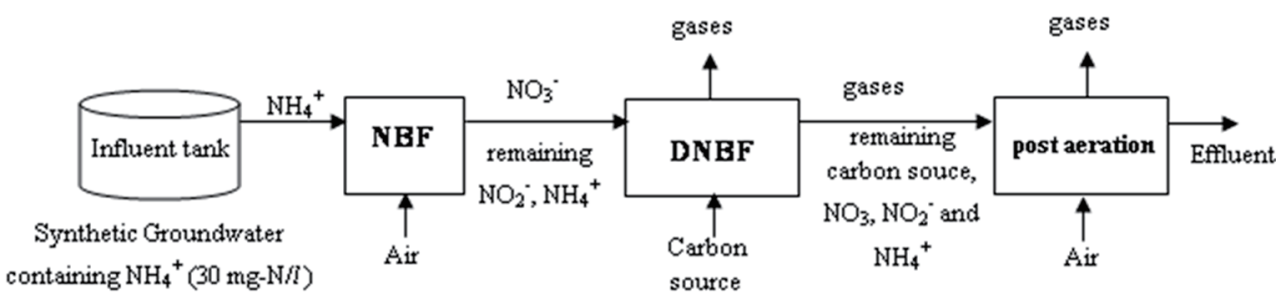

b)

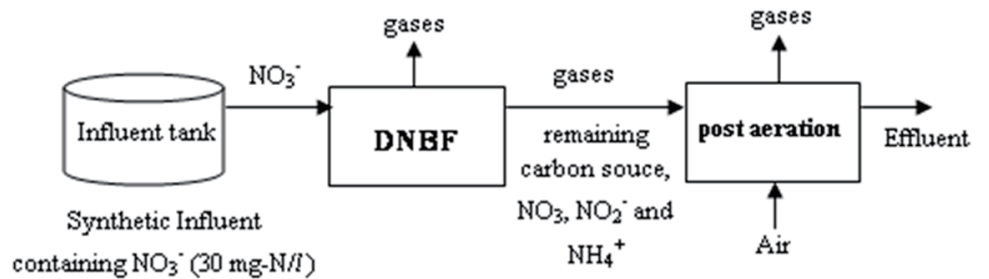

Fig. 3 Schematic diagram of a) the combination of nitrification and denitrification process used NBF and DNBF reactors and $b$ ) the denitrification process used DNBF reactor 
$0.072 \mathrm{~kg}-\mathrm{N} / \mathrm{m}^{3} / \mathrm{d}$. Then, the $\mathrm{NO}_{3}^{-}$loading rates were increased in a stepwise manner by decreasing the HRT to evaluate the denitrification capacity of the DNBF reactor. The influent $\mathrm{NO}_{3}^{-}$concentration was increased to $50 \sim 90 \mathrm{mg}-\mathrm{N} / \mathrm{L}$ from day 148 to examine denitrification efficiency of the $\mathrm{DNBF}$ reactor at a higher $\mathrm{NO}_{3}^{-}$contaminated level. The stirrer speed and $\mathrm{C} / \mathrm{N}$ ratios were changed during the experiment to investigate the optimum conditions and to find the minimum $\mathrm{C} / \mathrm{N}$ ratio for effective treatment. Influent and effluent samples were taken almost daily for water quality analysis. Effluent SS concentrations were measured for calculation of sludge yield. Post aeration was needed after denitrification in order to remove byproduct gases such as nitrogen and hydrogen sulfide. Oxygen supplementation for oxidation of remaining ethanol, $\mathrm{NO}_{2}^{-}$and $\mathrm{NH}_{4}{ }^{+}$were also conducted in this step.

Synthetic influents Two media were used in this study. In the first period, NBF effluent was used as influent for the DNBF reactor. Synthetic influent used for the NBF reactor was similar in composition with the polluted groundwater of Hanoi as mentioned in previous study reports ${ }^{3,4)}$. In the second period, the NBF and DNBF reactors were separated and tap water supplemented with $30 \mathrm{mg} \mathrm{NO}_{3}-\mathrm{N} / l$ was used as synthetic influent for DNBF in order to investigate the nitrogen removal performance of the $\mathrm{DNBF}$ reactor. An influent containing a higher $\mathrm{NO}_{3}{ }^{-}$ concentration of $50 \sim 90 \mathrm{mg} \mathrm{NO}_{3}-\mathrm{N} / l$ was used also in this study. The main components and parameters of influents for the NBF and DNBF reactors are shown in Table 1. An ethanol-phosphate solution was fed separately using a peristaltic pump at $\mathrm{C} / \mathrm{N}$ ratios in the range of 2.5 to 1 . Phosphate was fed as nutrient for biomass growth at $\mathrm{P} / \mathrm{N}$ ratios of 0.04 .

Batch experiments For evaluation of the denitrifying capacity of the seed activated sludge and the activated sludge from the swim-bed attached-growth reactor, batch denitrification experiments were conducted at $25^{\circ} \mathrm{C}$ in 1 -liter elrenmyer flasks. A specific amount of denitrifying sludge was added to each flask with medium containing $303 \mathrm{mg}$ $\mathrm{NaNO}_{3}$ and $0.26 \mathrm{ml} \mathrm{C}_{2} \mathrm{H}_{5} \mathrm{OH} 95 \%$ (C/N ratio of 2). Tap water was used for dilution to give an initial $\mathrm{NO}_{3}{ }^{-}$concentration of $50 \mathrm{mg}-\mathrm{N} / \mathrm{L}$. $\mathrm{KH}_{2} \mathrm{PO}_{4}$ was also added (to $1.0 \mathrm{mg} \mathrm{P} / l$ ) as a nutrient for biomass growth. Anoxic conditions were maintained by purging with argon gas. Shaker mixing was at a speed of $100 \mathrm{rpm}$ at $25^{\circ} \mathrm{C}$. Mixed liquor samples were taken every hour and supernatants obtained by centrifugation (3,000 $\mathrm{g}$ for $10 \mathrm{~min})$ were used for water quality analyses.

Analytical methods Influent and effluent $\mathrm{NO}_{3}{ }^{-}, \mathrm{NO}_{2}^{-}$and $\mathrm{NH}_{4}{ }^{+}$were analyzed almost daily (at least 2 times a week) for the evaluation of nitrogen removal performance. In addition, total nitrogen ( $\mathrm{TN}$ ) was analyzed frequently for the evaluation of nitrogen removal. According to EPA methods ${ }^{19)}, \mathrm{NO}_{3}{ }^{-}$ was determined by using the UV spectrophotometer colorimetric brucine method (352.1). According to standard methods ${ }^{20)}$, $\mathrm{NO}_{2}{ }^{-}$was determined by the colorimetric method (4500- $\left.\mathrm{NO}_{2}^{-} \mathrm{B}\right), \mathrm{COD}$ by the closed reflux colorimetric (5220 D) and alkalinity by the titration method (2320 B). Effluent Total$\mathrm{N}$ was determined on well-settled samples, thus not reflecting nitrogen in the biomass or sludge (though not excluding the soluble organic component). By the persulfate method all nitrogen is oxidized to $\mathrm{NO}_{3}{ }^{-}$, which was measured using the UV spectrophotometric screening method $\left(4500-\mathrm{NO}_{3}{ }^{-} \mathrm{B}\right.$ ) (the use of an ion analyzer was ineffective in this case due to interference from compounds in the persulfate solution).

Table 1 Composition of synthetic influents for NBF and DNBF reactors

\begin{tabular}{cccc}
\hline \multirow{2}{*}{$\begin{array}{c}\text { Component and } \\
\text { parameter }\end{array}$} & $\begin{array}{c}\text { Influent for } \\
\mathrm{NBF}\end{array}$ & \multicolumn{2}{c}{ Influent for DNBF } \\
\cline { 3 - 4 } $\mathrm{NO}_{3}^{-}(\mathrm{mg} \mathrm{N} / l)$ & $0.6-3$ & $20-30$ & $30 ; 50 \sim 90$ \\
$\mathrm{NO}_{2}^{-}(\mathrm{mg} \mathrm{N} / l)$ & 0 & $0-3$ & 0 \\
$\mathrm{NH}_{4}^{+}(\mathrm{mg} \mathrm{N} / l)$ & 30 & $0-3.5$ & 0 \\
$\mathrm{pH}$ & $7.5-8.4$ & $6.8-7.5$ & $7.1-7.6$ \\
$\mathrm{DO}(\mathrm{mg} / l)$ & $7-8.5$ & $4.0-6.0$ & $7.0-8.5$ \\
$\begin{array}{c}\text { Alkalinity } \\
\left(\mathrm{mg}-\mathrm{CaCO}_{3} / l\right)\end{array}$ & $220-250$ & $20-80$ & $70-90$ \\
\hline
\end{tabular}

* BF effluent 
$\mathrm{NH}_{4}{ }^{+}$was determined by the OPP method ${ }^{21)}$. A UV-visible spectrophotometer (U-2010, Hitachi, Japan) was used for absorption measurements. Reactor $\mathrm{pH}$ was monitored by using a pH meter (IM-22P; TOA Electronics, Ltd., Tokyo, Japan) and DO by a DO meter (OM 51; Horiba, Ltd., Kyoto, Japan). The effluent suspended solids (SS), mixed liquor suspended solids (MLSS) and volatile suspended solid (VSS) were measured weekly for the evaluation of sludge retention capacity using standard methods ${ }^{20)}$

\section{RESULTS AND DISCUSIONS}

Kinetic analysis Batch experiments were conducted to determine the kinetic parameters of the denitrifying sludge. Two sludge samples were taken from DNBF reactor on days 5 and 45 (HRT, 10 hours). The Michaelis-Menten kinetic model was applied. Fig. 4 shows the Lineweaver-Burk's plots used for the determination of the kinetic constants for denitrification. From these plots, the specific maximum denitrification rate $\left(V_{\mathrm{m}}\right)$ and saturation constant $\left(K_{m}\right)$ were determined to be:

$V_{\mathrm{m}}=0.44 \mathrm{mg}-\mathrm{N} / \mathrm{mg} \mathrm{VSS} / \mathrm{d}$ and $K_{m}=25.1 \mathrm{mg}$ $\mathrm{NO}_{3}-\mathrm{N} / l$ for the sludge sample of day 5

$V_{\mathrm{m}}=0.76 \mathrm{mg}-\mathrm{N} / \mathrm{mg} \mathrm{VSS} / \mathrm{d}$ and $K_{m}=4.06 \mathrm{mg}$ $\mathrm{NO}_{3}-\mathrm{N} / l$ for the sludge sample of day 45

A much higher maximum denitrification rate and lower saturation constant were obtained for the denitrifying sludge which had a longer acclimation time in the swimbed DNBF reactor, thus demonstrating a higher affinity of the DNBF sludge for the substrate.

Denitrification performances Operational conditions for the DNBF process are shown in Table 2. The whole experimental period was divided into 11 runs. Fig. 5 shows the changes in HRT, VLR, influent and effluent nitrogen concentrations, and denitrification efficiencies for the DNFB reactor during

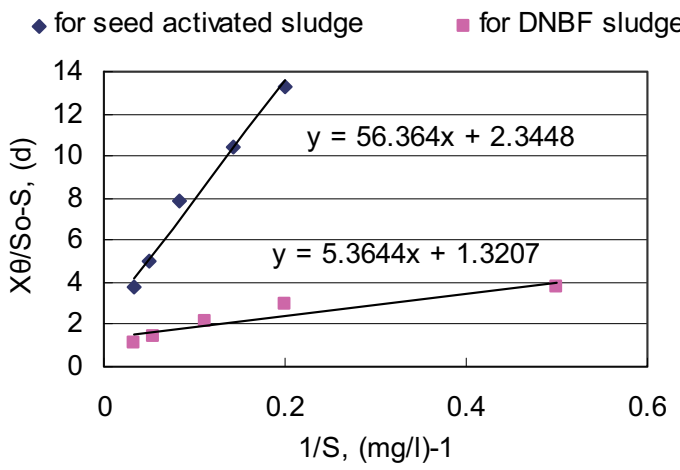

Fig. 4 Linerweaver-Burk's plots for determination of kinetic coefficients $K_{\mathrm{m}}$ and $V_{\mathrm{m}}$ for seed activated sludge and DNBF sludge

Table 2 Operating conditions for DNBF reactor (averages)

\begin{tabular}{|c|c|c|c|c|c|c|c|}
\hline Run & $\begin{array}{l}\text { Days of } \\
\text { operation } \\
\text { (d) }\end{array}$ & $\begin{array}{c}\text { Inf. } \mathrm{NO}_{3}-\mathrm{N} \\
\text { conc. } \\
(\mathrm{mg} / l)\end{array}$ & $\begin{array}{l}\mathrm{HRT} \\
(\mathrm{h})\end{array}$ & $\begin{array}{c}\mathrm{VLR}^{*} \\
\left(\mathrm{~kg} \mathrm{NO}_{3}-\right. \\
\left.\mathrm{N} / \mathrm{m}^{3} / \mathrm{d}\right) \\
\end{array}$ & $\begin{array}{l}\text { Stirrer speed } \\
\quad(\mathrm{rpm})\end{array}$ & $\begin{array}{c}\text { Reactor } \\
\text { bulk DO } \\
(\mathrm{mg} / l)\end{array}$ & $\mathrm{C} / \mathrm{N}$ ratio \\
\hline $\mathrm{A}$ & $(1-29)$ & $23-29$ & 10 & 0.072 & 1600 & $1.2 \sim 1.5$ & $2 \sim 2.5$ \\
\hline B & $(30-35)$ & 30 & 10 & 0.072 & 1600 & $1.2 \sim 1.5$ & $2 \sim 2.5$ \\
\hline $\mathrm{C}$ & $(36-49)$ & 30 & 10 & 0.072 & 2000 & $4.0 \sim 5.2$ & $2 \sim 2.5$ \\
\hline $\mathrm{D}$ & $(50-59)$ & 30 & 10 & 0.072 & 1600 & $0.2 \sim 1.2$ & $2 \sim 2.5$ \\
\hline $\mathrm{E}$ & $(60-78)$ & 30 & $7-3$ & $0.10-0.24$ & 1600 & $0.2 \sim 1.2$ & 2 \\
\hline $\mathrm{F}$ & $(79-119)$ & 30 & $3-1.5$ & $0.24-0.48$ & 1000 & $0 \sim 0.5$ & 2 \\
\hline G & $(120-133)$ & 30 & 1 & 0.72 & 1000 & $0 \sim 0.5$ & 2 \\
\hline $\mathrm{H}$ & $(134-147)$ & 30 & 0.5 & 1.44 & 1000 & $0 \sim 0.5$ & 2 \\
\hline I & $(148-155)$ & 50 & 1 & 1.2 & 1000 & $0 \sim 0.5$ & 2 \\
\hline $\mathrm{K}$ & $(156-160)$ & 60 & 1 & 1.44 & 1000 & $0.3 \sim 0.7$ & 2 \\
\hline $\mathrm{L}$ & $(161-165)$ & 90 & 1 & 2.16 & 1000 & $0.3 \sim 0.7$ & 2 \\
\hline M & $(166-170)$ & 30 & 1 & 0.72 & 1000 & $0.3 \sim 0.7$ & 1 \\
\hline $\mathrm{N}$ & $(171-173)$ & 30 & 1 & 0.72 & 1000 & $0.3 \sim 0.7$ & 0.8 \\
\hline
\end{tabular}

* VLR: Volumetric loading rate 
Runs A-G. An HRT of 10 hours corresponding to a volumetric loading rate (VLR) of 0.072 $\mathrm{kg}-\mathrm{N} / \mathrm{m}^{3} / \mathrm{d}$ was maintained during Runs AD.

In Run A, the DNBF reactor was fed nitrified influent (NBF effluent). In this period, the NBF reactor had just restated and was operated at a short HRT of 5 hours
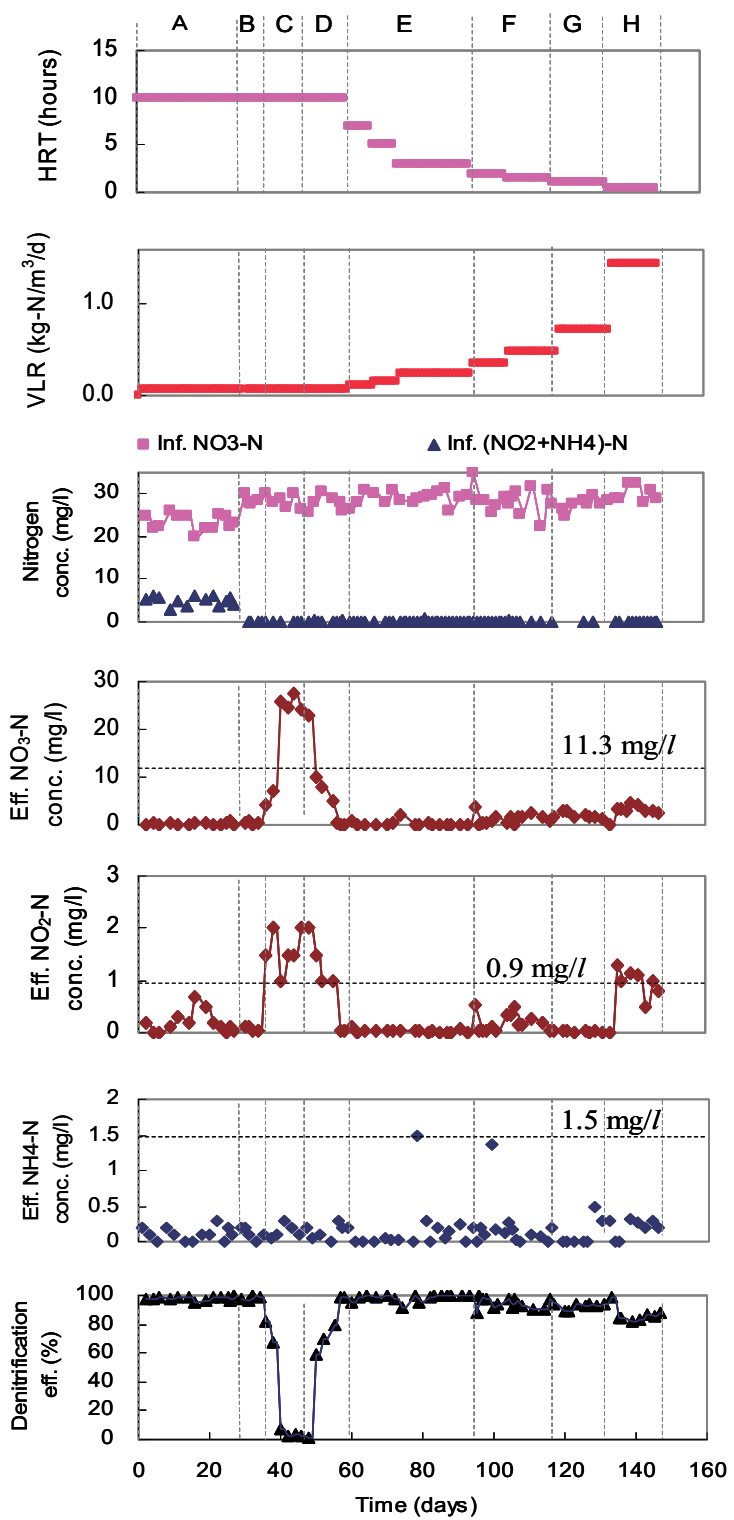

Fig. 5 Changes in HRT, VLR, influent and effluent nitrogen concentrations and denitrification efficiencies for DNBF during Runs A-H for supplying $1.4 \mathrm{l} / \mathrm{h}$ to the DNBF reactor (DNBF operated at HRT of 10 hours). Nitrification efficiencies of about 80 and $90 \%$ and high effluent $\mathrm{NH}_{4}{ }^{+}$concentrations of $2 \sim 4.3 \mathrm{mg} / l$ were obtained for the NBF reactor in this period.

The DNBF process influent contained 23$26.5 \mathrm{mg} \mathrm{NO}-\mathrm{N} / l$ and 2.5 6 $\mathrm{mg}\left(\mathrm{NO}_{2}+\mathrm{NH}_{4}\right)^{-}$ $\mathrm{N} / l$. Influent $\mathrm{DO}$ and $\mathrm{pH}$ levels were in range of $4 \sim 6 \mathrm{mg} / l$ and $6.8 \sim 7.4$, respectively. The stirrer speed was set at $1,500 \mathrm{rpm}$ and the observed bulk DO concentrations were $1.2 \sim 1.5 \mathrm{mg} / \mathrm{l}$ for the DNBF reactor during this run. The results showed that effluent $\mathrm{NO}_{2}-\mathrm{N}, \mathrm{NO}_{3}-\mathrm{N}, \mathrm{NH}_{4}-\mathrm{N}$ (Fig. 5) and $\mathrm{TN}$ for the DNBF process were close to zero during this run demonstrating that nitrogen was effectively removed and both nitrification and denitrification occurred in the DNBF reactor. Denitrification efficiencies remained high at $98 \sim 100 \%$ with a high bulk DO of $1.2 \sim 1.5$ $\mathrm{mg} / \mathrm{l}$ while previous studies reported that denitrification rate decreased to zero when DO reach $1.0 \mathrm{mg} / \mathrm{l}^{8}$. These different results can be explained by using the theoretical assumption which is presented in Fig. 6a. A large sludge amount was retained on biofringe creating a thick biofilm with the thickness ranging from 2 to $15 \mathrm{~mm}$. Denitrifying biomass was also formed as flock with flock size in the range of $2 \sim 12 \mathrm{~mm}$ (Fig. 7). The previous studies have been demonstrated that DO concentrations in the biofilm strongly depend on the bulk DO concentrations, thickness of biofilm and diffusion factor. DO levels in the biofilm decrease from outside to inside layers of the biofilms or flocks, clusters. Nitrification can occur in the outside layers (aerobic zone) of the biofilm where oxygen is available and denitrification can occur in the deeper layers (anoxic zone) of the biofilm, where DO is close to zero.

From day 30, the NBF and DNBF reactors were separated, and a medium consisting of $30 \mathrm{mg} \mathrm{NO}-\mathrm{N} / l$ was used as influent for the $\mathrm{DNBF}$ reactor. Influent $\mathrm{DO}$ and $\mathrm{pH}$ levels were in the ranges of $7.0 \sim 8.5 \mathrm{mg} / l$ and 7.1 7.6, respectively. The DNBF reactor obtained high denitrification efficiencies of $98 \sim 100 \%$ in Run B. From day 36 the stirrer speed was increased to $2,000 \mathrm{rpm}$ to improve circulation of water through the biological 
zone (Run C). Bulk DO concentrations in the biological zone increased to $4.0 \sim 5.2 \mathrm{mg} / \mathrm{l}$ during this run. Denitrification efficiencies decreased sharply during this run and dropped to zero at days 44-48. As shown in Fig. 6b, the high bulk reactor DO levels resulted in enlargement of the aerobic zones, which led to the anoxic zones becoming smaller and the denitrification becoming weaker. From these results, it was found that denitrification was inhibited at DO concentration of $4 \mathrm{mg} / l$ and stopped when DO concentrations reach to $5 \mathrm{mg} / \mathrm{l}$ in the swim-bed DNBF reactor. High stirrer speed resulting on higher water flow and cycle was a reason for the higher bulk DO levels in the DNBF reactor due to oxygen diffusion from the air. High water flow speed through the biological zone at high stirrer speeds is also a reason for high DO levels in the biofilm due to the high diffusion of oxygen. At stirrer speed of $1500 \mathrm{rpm}$, water flow velocity thought the $\mathrm{BF}$ zone (updraft section) was about $12 \mathrm{~cm} / \mathrm{s}$ and that was $22 \mathrm{~cm} / \mathrm{s}$ at stirrer speed of $2000 \mathrm{rpm}$. When the stirrer speed was reduced again to about 1,500 rpm from day 50, the bulk DO concentration decreased to less than $1.2 \mathrm{mg} / \mathrm{l}$ in Run D and nitrogen removal efficiencies increased sharply to $99 \%$ at day 56. Then $\mathrm{NO}_{3}^{-}$VLRs were increased stepwise to $0.72 \mathrm{~kg}-\mathrm{N} / \mathrm{m}^{3} / \mathrm{d}$ corresponding to an HRT as short as one hour (Runs E, F and G). High denitrification efficiencies of $90 \sim 100 \%$ were obtained in these Runs. Very small decrease in denitrification efficiencies occurred when the VLR was increased sharply. This demonstrated that DNBF denitrifying bacteria were in sufficient number and quickly adapted to a sharp increase in VLR.

Denitrification efficiencies decreased to $80 \sim 90 \%$ in Run $H$ when the VLR was increased to an extremely high level of 1.44 $\mathrm{kg}-\mathrm{N} / \mathrm{m}^{3} / \mathrm{d}$ (HRT was 0.5 hour), which resulted in higher effluent TN levels of $3 \sim 6$ $\mathrm{mg} / l$, but these values were still below the maximal acceptable nitrogen concentration for drinking water ${ }^{1}$. Fig. 8 shows the nitrogen removal rate as a function of loading rate. These results were high in comparison to that of other drinking water denitrification processes shown in Table 3. a) DO 1.2 1.5 mg/L

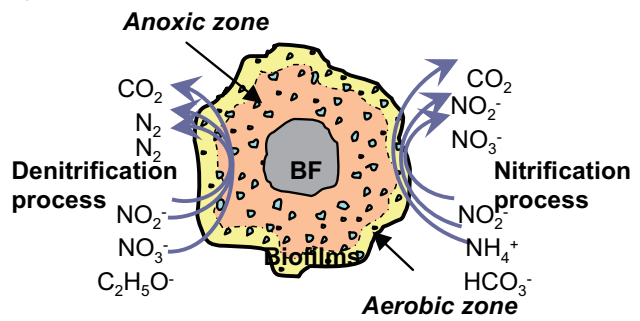

b) $\mathrm{DO} 4.0 \sim 5.2 \mathrm{mg} / \mathrm{L}$

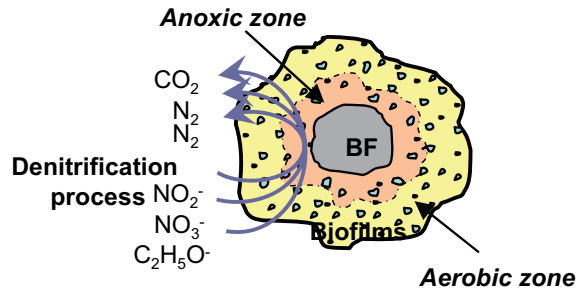

c) DO close to zero

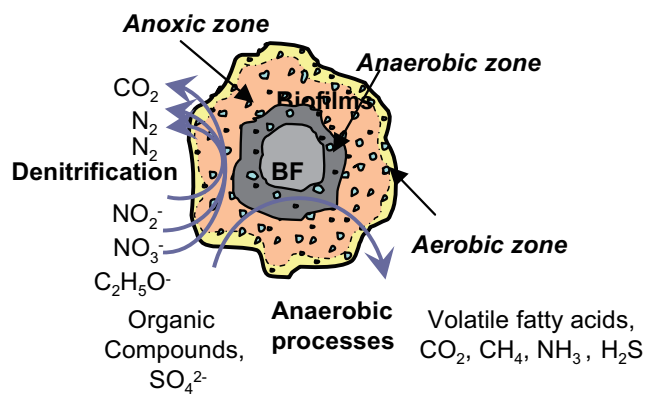

Fig. 6 Biological reaction within bacterial biofilms

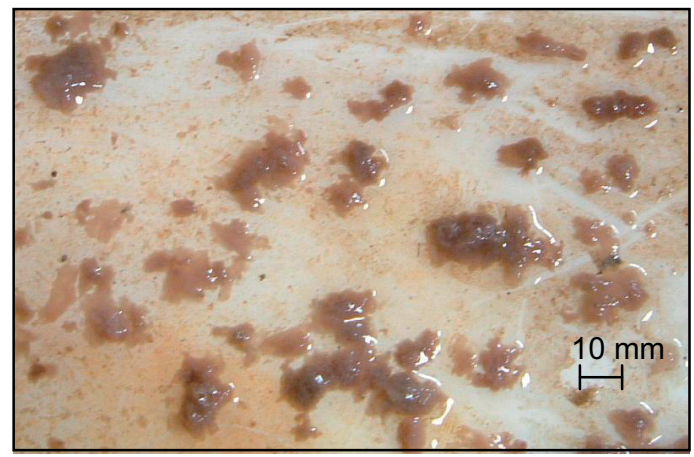

Fig. 7 Photograph of sludge detached from the DNBF biomass in flock shape 
Accumulation of excess sludge resulted in an enlargement of the anaerobic zone. This phenomenon resulted in the production of hydrogen sulfide smell and increases in effluent $\mathrm{NH}_{4}{ }^{+}$concentration as well as COD removal (Fig. 6c). By using air back-washing (20 l/min for 1min), most of the sludge detached from the $\mathrm{BF}$ material and then reattached while some washed out of the reactor. Denitrification efficiencies decreased $2 \sim 4 \%$ on the day of sludge washing and then again increased indicating that the reattached sludge was sufficient for denitrification process at the applied VLR.

From day 148, in order to examine the adaptation of the DNBF reactor to treating higher $\mathrm{NO}_{3}^{-}$contaminated groundwater, the HRT was kept at 1 hour and influent $\mathrm{NO}_{3}{ }^{-}$ concentration was increased to $50 \sim 90 \mathrm{mg}-\mathrm{N} / l$ (Run I, K, L). High denitrification efficiencies of $90 \sim 95 \%$ at VLR of $1.2 \mathrm{~kg}-\mathrm{N} / \mathrm{m}^{3} / \mathrm{d}$ were achieved during Run I. During Run K, when

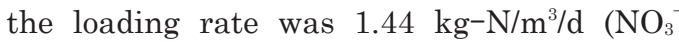

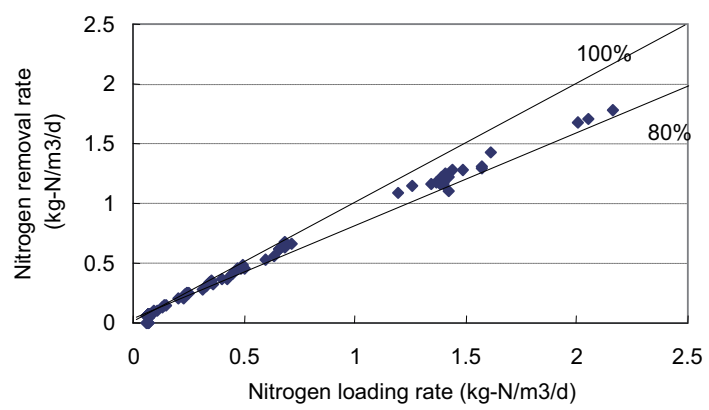

Fig. 8 Nitrogen removal rate as a function of loading rate concentration was $60 \mathrm{mg}-\mathrm{N} / l)$, denitrification efficiencies of $88 \sim 90 \%$ were achieved, with effluent $\mathrm{TN}$ in a range of $6 \sim 7 \mathrm{mg} / l$. These results demonstrated that for the same loading rate of $1.44 \mathrm{~kg} / \mathrm{m}^{3} / \mathrm{d}$, a higher influent $\mathrm{NO}_{3}-\mathrm{N}$ concentration and longer HRT or contact time (HRT of 1 hour versus 0.5 hour) did not have much influence on denitrification efficiency. These results demonstrated that the DNBF process had a high adaptability for treating higher nitrate concentration influent. At a high loading rate of $2.16 \mathrm{~kg}-$ $\mathrm{N} / \mathrm{m}^{3} / \mathrm{d}$ during Run $\mathrm{L}$, denitrification efficiencies decreased to $82 \sim 86 \%$, resulting on high effluent TN levels of up to 11.6 16.0 $\mathrm{mg}-\mathrm{N} / l$. Effluent $\mathrm{NO}_{3}^{-}$and $\mathrm{NO}_{2}^{-}$were 5.7 6.9 and $4.6 \sim 10.3 \mathrm{mg}-\mathrm{N} / l$, respectively. Higher nitrogen removal rates of $1.73 \sim 1.84 \mathrm{~kg}-\mathrm{N} / \mathrm{m}^{3} /$ $\mathrm{d}$ were achieved in this run, but effluent TN concentrations exceed the maximum contaminated limit for $\mathrm{TN}$ in drinking water. Thus a longer HRT is required.

DO influence As mentioned in the previous section, the DO concentration in the DNBF reactor affected denitrification rate. The denitrification rate decreased sharply and even stop when reactor bulk DO increased to $4 \sim 5.2$ during Run C. At DO concentrations of $1.2 \sim 1.5 \mathrm{mg} / \mathrm{l}$ during Run $\mathrm{A}, \mathrm{B}, \mathrm{D}, \mathrm{E}$ and $0.3 \sim 0.7 \mathrm{mg} / l$ during Run $\mathrm{H} \sim \mathrm{L}$, effective denitrification could be achieved with high denitrification efficiencies and high $\mathrm{NO}_{3}{ }^{-}$ loading rates up to $1.44 \mathrm{~kg}-\mathrm{N} / \mathrm{m}^{3} / \mathrm{d}$. At very low DO concentrations of closed to zero and excess sludge accumulated during Run F, anaerobic reaction occurred resulting on the production of hydrogen sulfide smell and

Table 3 Comparison of denitrification performance for drinking water production in different systems

\begin{tabular}{ccccc}
\hline System & Electron donor & $\begin{array}{c}\text { Removal rate } \\
\left(\mathrm{kg} \mathrm{NO}-\mathrm{N}^{3} / \mathrm{d}\right)\end{array}$ & Temp. ( $\left.{ }^{\circ} \mathrm{C}\right)$ & Reference \\
\hline Fluidized-bed Bioreactor & Hydrogen & 0.34 & $18-23$ & 25 \\
Fixed-bed Bioreactor & Ethanol & 0.75 & 12 & 26 \\
Fixed-bed Bio-electrochemical reactor & Hydrogen & 0.25 & 25 & 27 \\
Immobilized Bioreactor & Starch & 0.46 & 25 & 32 \\
Membrane Bioreactor & Ethanol & 0.30 & $\mathbf{1 3}$ & This study \\
Swim-bed DNBF reactor & Ethanol & $\mathbf{1 . 8 4}$ & &
\end{tabular}


increases in effluent $\mathrm{NH}_{4}^{+}$and $\mathrm{COD}$ consumption.

Temperature influence Denitrification was affected by temperature, though it is less sensitive in comparison with that of nitrification. As similar to other biological process, optimum temperature for denitrification is in range of $30 \sim 35^{\circ} \mathrm{C}$. At low temperatures, denitrification decreased markedly due to the higher oxygen solubility, thus decreasing the biological denitrification rate. Gauntlett and Craft reported that, with every $10^{\circ} \mathrm{C}$ increased in temperature, a doubling of denitrification rate is possible ${ }^{22}$. The DNBF reactor temperature was kept at $25^{\circ} \mathrm{C}$ through most of the study. During Runs K, L, M and $\mathrm{N}$, at high loading rates of $1.44 \sim 2.16 \mathrm{~kg}-\mathrm{N} /$ $\mathrm{m}^{3} / \mathrm{d} \quad\left(30 \sim 90 \mathrm{mg}\right.$ influent $\mathrm{NO}_{3}-\mathrm{N} / l$, HRT 1 hour), the temperature in the reactor was reduced to $12 \sim 13^{\circ} \mathrm{C}$ due to very cold weather even though the heater was set at $25 \sim 30^{\circ} \mathrm{C}$. Reactor bulk DO levels were in a range of $0.5 \sim 0.7 \mathrm{mg} / l$ during these runs and no decreases in denitrification efficiencies were observed. High denitrification efficiencies of 90\% were still achieved during Runs K, M and $\mathrm{N}$.

Low sludge growth rate caused by low temperature might not affect denitrification rate because the $\mathrm{BF}$ material can retain a large amount of denitrifying biomass. As mentioned before, a large amount of sludge attached on biofringe was composed of thick biofilms, and DO concentrations in denitrification zone within biofilm was not the same as reactor bulk DO concentrations. Thus, denitrification was not inhibited by a higher DO levels in the DNBF reactor due to low operational temperature condition. These results demonstrated that effective denitrification could be achieved even at a low temperature of $12^{\circ} \mathrm{C}$ using the DNBF process.

\section{Carbon to nitrogen $(\mathrm{C} / \mathrm{N})$ ratio and COD consumption $\quad \mathrm{C} / \mathrm{N}$ ratio was maintained at} a high value of 2 2.5 throughout most of time of the experiment to ensure that organic substrate was always available (as shown in Table 2). Changes in influent and effluent $\mathrm{NO}_{3}-\mathrm{N}$ and $\mathrm{COD}$ concentrations during the
DNBF experimental runs are shown in Fig. 9. High organic substrate degradations of 60 90\% were observed during Runs A, B, and $\mathrm{D}$, with $\mathrm{mg}$ COD consumption per $\mathrm{mg}$ of $\mathrm{NO}_{3}-\mathrm{N}$ denitrified to nitrogen gas were calculated to be 5.0 to 6.8 and the $\mathrm{C}_{\text {used }} / \mathrm{N}$ ratios ranging from 1.41 to 1.64 were estimated during these Runs ( $1 \mathrm{mg} \mathrm{C}$ was approximately $3.9 \mathrm{mg}$ COD). These values were high in comparison with the calculated value from the stoichiometry of the denitrification process (Eq. 4-1), which shows that denitrification of $1 \mathrm{mg} \mathrm{NO} \mathrm{N}_{3}-\mathrm{N}$ to nitrogen gas consume $1.05 \mathrm{mg}$ C. These were also higher than the results reported in previous studies $^{10,26,27)}$. The COD removals remained at 40 50\% during days 38 42 (Run C), when the reactor bunk DO reach to about $5 \mathrm{mg} / \mathrm{l}$ and denitrification decreased to zero. This clearly showed that organic carbon acted as an electron donor for nitrate reduction as well as a source of cellular substrate for biological respiration in anoxic denitrification and it also influenced the depletion of oxygen in the DNBF reactor (aerobic activity). The high stirrer speed of 1,500 2,000 rpm could be the only reason for oxygen diffusion from the air. This explanation was strongly confirmed when stirrer speed was reduced to 1,000 rpm and COD degradation subsequently decreased to $38 \sim 46 \%$ during Run E. COD consumption per mg of $\mathrm{NO}_{3}-\mathrm{N}$ denitrified to nitrogen gas was calculated to be 3.4 to 4.2 during this period. Then these values again increased to 5.0 6.2 during days 70 74, which might be because the COD degradation increased due to anaerobic biological activity, as noted in the previous section. After sludge

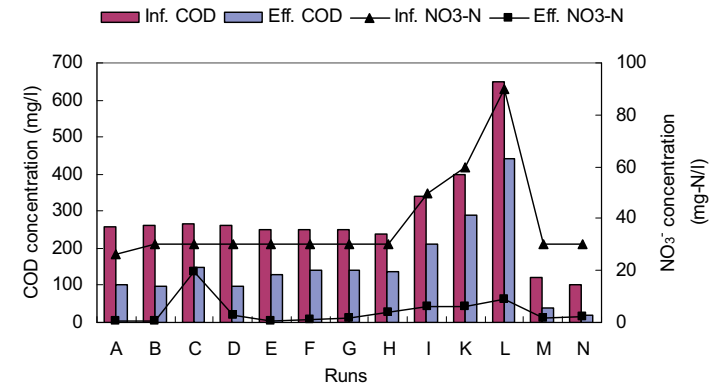

Fig. 9 Changes in influent and effluent $\mathrm{COD}$ and $\mathrm{NO}_{3}-$ $\mathrm{N}$ during experiment for the DNBF reactor 
washing, sludge was partly washed out, these values again decreased. During Runs I, K and $\mathrm{L}$, at high loading rate of $1.2 \sim 2.16 \mathrm{~kg}^{-}$ $\mathrm{N} / \mathrm{m}^{3} / \mathrm{d}$, the COD consumptions per $\mathrm{mg}$ of $\mathrm{NO}_{3}-\mathrm{N}$ denitrified to nitrogen gas were 2.7 3.2 mg, approximately. The $\mathrm{C}$ consumption per mg $\mathrm{NO}_{3}-\mathrm{N}$ denitrified to nitrogen gas were calculated to be 0.7 to 0.93 during Runs F-L. Changes in $\mathrm{mg} \mathrm{COD} / \mathrm{mg}$ $\mathrm{NO}_{3}-\mathrm{N}_{\text {removed }}$ ratio and bulk DO for the DNBF reactor are shown in Fig. 10. The $\mathrm{mg} \mathrm{C}$ consumed per $\mathrm{mg} \quad \mathrm{NO}_{3}-\mathrm{N}$ denitrified to nitrogen gas were calculated to be 0.7 to 0.93 during Runs F-L.

Very high denitrification efficiencies of 80 $100 \%$ resulting in low effluent TN levels of $0 \sim 6 \mathrm{mg} / l$ in the effluent were obtained throughout the experiment for treating 30 mg $\mathrm{NO}_{3}-\mathrm{N} / l$ influent with high $\mathrm{NO}_{3}{ }^{-} \mathrm{VLR}$ of up to $1.44 \mathrm{~kg}-\mathrm{N} / \mathrm{m}^{3} / \mathrm{d}$. These values were much lower compared to the WHO maximum allowable nitrate level (11.3 $\mathrm{mg}-\mathrm{N} / l)$, indicating that the lower $\mathrm{C} / \mathrm{N}$ ratio is acceptable. Lower $\mathrm{C} / \mathrm{N}$ ratio of 1 and 0.8 were applied during Runs $\mathrm{M}$ and $\mathrm{N}$ for determining the lowest acceptable $\mathrm{C} / \mathrm{N}$ ratio in continuous denitrification experiment for treating nitrified Hanoi groundwater. The influent contained $30 \mathrm{mg} \mathrm{NO}{ }_{3}-\mathrm{N} / l$ and HRT was 1 hour during these Runs. Denitrification efficiencies of about 91 and $88 \%$ were observed for Runs $\mathrm{M}$ and $\mathrm{N}$, respectively. The effluent $\mathrm{NO}_{3}{ }^{-}$and $\mathrm{NO}_{2}^{-}$concentrations of about 2.7 3.3 and 0.01 0.15 $\mathrm{mg}-\mathrm{N} / l$, respectively, during these runs, were still much lower in comparison to the maximum allowable level set by WHO, so the applied $\mathrm{C} / \mathrm{N}$ ratio could be more reduced.

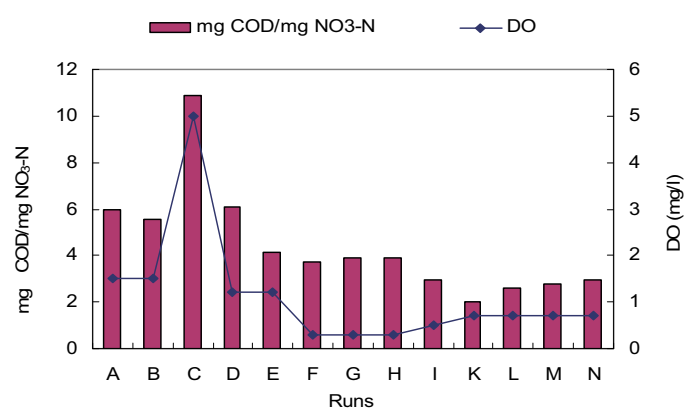

Fig. 10 Change in $\mathrm{COD} / \mathrm{mg} \mathrm{NO}_{3}-\mathrm{N}$ removed and bulk $\mathrm{DO}$ for the DNBF reactor
Alkalinity production and $\mathbf{p H}$ Influent alkalinity levels were in a range of 20 90 $\mathrm{mg}-\mathrm{CaCO}_{3} / l$ and effluent alkalinities were between 90 and $190 \mathrm{mg}-\mathrm{CaCO}_{3} / l$ and the reactor $\mathrm{pH}$ levels changed from 7.1 to 8.1 during Runs $\mathrm{A} \sim \mathrm{H}$, which is within the optimum range for denitrification ${ }^{29)}$. No $\mathrm{pH}$ adjustment was requited for efficient denitrification in the DNBF reactor. Considering that $7.1 \mathrm{mg}$ alkalinity was consumed for 1 $\mathrm{mg}$ of $\mathrm{NH}_{4}-\mathrm{N}$ oxidized as the results found for nitrification study ${ }^{3)}$, alkalinity production per $\mathrm{mg}$ of nitrate nitrogen reduced during Run A was $3.5 \mathrm{mg} \mathrm{CaCO}_{3}$ and during Runs $\mathrm{B} \sim \mathrm{E}$, these values were estimated to be in the range of $3 \sim 4 \mathrm{mg}$. These values were in accordance to that of other studies ${ }^{30)}$, which have shown that $3.5 \mathrm{mg}$ alkalinity as $\mathrm{CaCO}_{3}$ is produced per $\mathrm{mg} \mathrm{NO}_{3}-\mathrm{N}$ reduced to nitrogen gas. High $\mathrm{NO}_{3}^{-}$influent concentrations of $60 \sim 90 \mathrm{mg} / \mathrm{l}$ resulted on high effluent alkalinity ranging from 250 to 280 $\mathrm{mg} / \mathrm{l}$ during Runs $\mathrm{K}$ and $\mathrm{L}$, respectively. Reactor $\mathrm{pH}$ levels increased up to 9.1 during these Runs. No significant reduction on nitrogen removal rates during these runs with high denitrification efficiencies of up to 90 and $86 \%$ were observed during Runs K and $\mathrm{L}$, respectively, at loading rates as high as $1.44 \sim 2.16 \mathrm{~kg} / \mathrm{m}^{3} / \mathrm{d}$.

Effluent SS, sludge yield, and sludge withdrawal Clear effluent with very low SS concentrations of $0 \sim 5 \mathrm{mg} / l$ were obtained with nitrate VLRs up to $0.48 \mathrm{~kg}-\mathrm{N} / \mathrm{m}^{3} / \mathrm{d}$. Effluent SS levels increased slightly to less than 10 and $15 \mathrm{mg} / \mathrm{l}$ at VLRs of 0.72 and $1.44 \mathrm{~kg}-\mathrm{N} / \mathrm{m}^{3} / \mathrm{d}$, respectively during Runs $\mathrm{G}$ and $\mathrm{H}$. These results demonstrated that the $\mathrm{BF}$ biomass carrier could retain high amounts of sludge. The end product of nitrogen gas escaped as gas bubbles, which bound to the suspended sludge and caused sludge to rise to the surface of the reactor. This sludge was estimated to be $0 \sim 5 \mathrm{mg}$ per litter of influent and needed to be removed frequently only during Runs F, G and H. Bulk MLSS concentrations during experiment were approximately the same as the SS concentrations in the effluent.

After a long operational period of 140 days, the effluent SS levels decreased to less than 
$5 \mathrm{mg} / \mathrm{l}$ event at high VLRs of $1.44 \mathrm{~kg}-\mathrm{N} / \mathrm{m}^{3} / \mathrm{d}$ and short HRT of one hour, and sludge on the water surface of the reactor was close to zero. Even without occasional back washing, no smell of hydrogen sulfide $\left(\mathrm{H}_{2} \mathrm{~S}\right)$ occurred and effluent ammonium levels closed to zero during this runs. These results demonstrated that sludge growth might be close to a stationary phase in this period. A total sludge amount in the DNBF reactor of $148 \mathrm{~g}$ was estimated at day 180 and the observed sludge yield $\left(\mathrm{Y}_{\mathrm{obs}}\right)$ of $0.29 \mathrm{~g} \mathrm{VSS} / \mathrm{g} \mathrm{NO}_{3}-\mathrm{N}$ removed was estimated for the first 180 days using Eq. 2. The average sludge retention time $(\theta)$ of 44 days was also estimated in this period using Eq. 3 when sludge yield $\mathrm{Y}$ and decay rate $k_{d}$ were 0.8 and $0.041 / d$, respectively, which were typical value for denitrifying sludge ${ }^{32}$. Further research is needed to investigate the denitrifying sludge growth rate as well as the sludge withdrawal rate under different operational conditions.

$$
\begin{aligned}
Y_{o b s} & =\frac{\left(\mathrm{C}_{t}-\mathrm{C}_{o}\right)+\sum_{i=1}^{n} C_{i}+\sum_{i=1}^{t}\left(C_{e f f}\right)_{i}}{\sum_{i=1}^{t} S_{i}} \\
Y_{o b s} & =\frac{Y}{1+k_{d} \theta_{c}}
\end{aligned}
$$

where:

$$
\begin{array}{ll}
Y_{o b s} & \begin{array}{l}
\text { observed sludge yield coefficient } \\
\text { (g-VSS/g- } \mathrm{NO}_{3}-\mathrm{N} \text { removed) }
\end{array} \\
\left(C_{\text {eff }}\right)_{i} & \begin{array}{l}
\text { amounnt of suspended solid in } \\
\text { effluent (g-VSS) }
\end{array} \\
C_{t} & \begin{array}{l}
\text { biomass in the reactor at time } \mathrm{t} \\
\text { (g-VSS) }
\end{array} \\
C_{o} & \begin{array}{l}
\text { biomass in the reactor at time zero } \\
\text { (g-VSS) }
\end{array} \\
\sum_{i=1}^{n} C_{i} & \begin{array}{l}
\text { withdrawal total sludge in } \mathrm{n} \text { times } \\
\text { during experiment (g-VSS) }
\end{array} \\
S_{i} & \begin{array}{l}
\text { amount of } \mathrm{NO}_{3}^{-} \text {removed }(\mathrm{g}-\mathrm{N}) \\
t
\end{array}
\end{array}
$$

\section{CONCLUSIONS}

An attached-growth DNBF swim-bed reactor was shown to be effective for achieving high nitrogen removal performances. Very low effluent TN levels of less than $2 \mathrm{mg} \mathrm{N} / l$ were obtained even at a high VLR of 0.72 $\mathrm{kg} / \mathrm{m}^{3} / \mathrm{d}$, corresponding to an HRT of only 1 hour with an influent of $30 \mathrm{mg} / l \quad \mathrm{NO}_{3}-\mathrm{N}$. Even at an extremely high VLR of $1.44 \mathrm{~kg} /$ $\mathrm{m}^{3} / \mathrm{d}$, high denitrification efficiencies of 80 $\sim 90 \%$ were obtained with effluent TN concentration of about $3 \sim 6 \mathrm{mg} / l$, which are well below the maximum allowable level for nitrogen in drinking water. The $\mathrm{BF}$ biomass carrier also offered a big advantage with respect to sludge retention capacity, which was demonstrated in low effluent SS levels even at an HRT as short as one-half hour.

The BF material is a hydrophilic acrylic composite that is light weight, inexpensive and durable; thus the BF swim-bed attachedgrowth process is easy to operate and maintain and is economically favorable. The NBF-DNBF system appears to be a good choice for removing ammonium from Hanoi groundwater. Also, as on extension of preliminary observations in this research, the possibility of using the swim-bed technology for denitrification at much higher loading rates (higher nitrate concentrations) conducive to industrial applications would be of value.

Finally, while simultaneous nitrification and denitrification with concurrent BOD removal were demonstrated here, the possibility of meaningfully using these reactions in a single unit process would be a stimulating avenue of study.

\section{ACKNOWLEDGEMENTS}

This study was supported by the core University Program between Japan Society for the Promotion and Science (JSPS) and National Center for Natural Science and Technology, Viet Nam.

\section{REFERENCES}

1) WHO: Guideline for drinking water quality. Volume I : Recommendation. World Health Organization, Geneva, 2000

2 ) Hanoi Clean Water Business Company: Assessment of Existing Groundwater Quality and treatment Effectiveness at the Water Treatment Plants managed by HCWBC, Report 2000

3 ) Doan, T. H., Kutsumoto R., Koyama, T., and 
Furukawa, K.: Nitrification of Ammoniumcontaminated Hanoi Groundwater using Swim-bed technology, Jap. J. Water Treat. Biol., 41 (3), 141-152 (2005)

4 ) Doan, T. H., Kutsumoto R., Koyama, T., Fuji, T., and Furukawa, K.: Evaluation of the swim-bed attached-growth process for nitrification of Hanoi Groundwater containing high levels of iron, Jap. J. Water Treat. Biol., 41 (4), 181-192 (2005)

5 ) McGraw-Hill: Wastewater Engineering: Treatment disposal reuse, 696-716 (1979)

6 ) Hellinga, C.A., Schellen A. J. C., Mulder J. W., van Loosdrecht M. C. M., and Heijnen, J. J.: The Sharon process: an innovative method for nitrogen removal from ammonium-rich waste water, Wat. Sci. Tech., 37, 135-142 (1998)

7 ) Sliekers, A. O., Derwort N., Gomez J. L., Strous M., Kuenen J. G., and Jetten M. S.: Completely autotrophic nitrogen removal over nitrite in one single reactor, Wat. Res., 36, 2475-2482 (2002)

8 ) Michael N., Annette B., Olav S., Mike J., Markus S., Marc S., Ingo S., Lars H. L., Lars P. N., and Niels P. R.: Kinetics, diffusional limitation and microscale distribution of chemistry and organisms in a CANON reactor, FEMS Mic. Eco. 51, 247-256 (2005)

9 ) Lieu, P. K., Hatozaki, R., Homan, H., and Furukawa, K.: Single-stage Nitrogen Removal using Anammox and Partial Nitritation (SNAP) for treatment of Synthetic Landfill Leachate, Jap. J. Water Treat. Biol., 41, 103-112 (2005)

10) McGraw-Hill: Principles of biological oxidation, Industrial water pollution control, USA, 173-187 (1989)

11) Savia G., Maria B., Marcelo Z., and Eugenio F.: Comperison of methanol, Ethanol, and Methane as Electron Donors for denitrification, Wat. Sci. Tech., 21, 313-320 (2004)

12) Magnus, Ch., Ewa, L., and Thomas, W.: A comparison between ethanol and methanol as carbon sources for denitrification, Wat. Sci. Tech., 30, 83-90 (1994)

13) Hallin, S. and Pell, M.: Metabolic Properties of Denitrifying bacteria adapting to methanol and Ethanol in activated sludge, Wat. Res., 32, 13-18 (1998)
14) Delanghe, B., Nakamura, F., Myoga, H., Magara, Y., and Guibal, E.: Drinking water denitrification in a membrane bioreactor. Wat. Sci. Tech., 30, 157-160 (1994)

15) (http://environment.dictonarypage.co.uk/ methanol)

16) Mateju, V., Cizinska, S., Krejei, J., and Janoch, T.: Biological water denitrification: a review. Enzyme Microbiol Technol, 14, 170-183 (1992)

17) Kapoor, A. and Viraraghavan, T.: Nitrate removal from Drinking water, J. Environ. Enginee. - Review, 371-380 (1997)

18) Rouse J., Daisuke Y., Cheng Y., Toichiro K., and Furukawa K.: Swim-bed Technology as an Innovative attached-growth Process for High-rate Wastewater Treatment, Jap. Water Treat. Biol., 40, 115-124 (2004)

19) US EPA: Methods for Chemical Analysis of Water and wastes, U. S. Environmental Protection Agency, 1983.

20) Clesceri, L. S., Eaton, A. D., and Greenberg, A. E.: Standard Methods for the Examination of Water and Wastewater, $19^{\text {th }}$ ed. American Public Health Association, Washington, D. C. (1995)

21) Kanda J.: Determination of ammonium in sea water base on the indophenol reaction with o-phenilphenol, Wat. Res., 29, 27462750 (1995)

22) Fahrner, S: Groundwater nitrate removal using a bioremendiation trech. Honours Thesis, Univ. of Western Australia, (2002)

23) Smith, R. L, Buckwalter, S. P., Repert, D. A., and Miller, D. N.: Small-scale, hydrogenoxidizing-denitrifying bioreactor for treatment of nitrate-contaminated drinking water, Wat. Res., 39, 2014-2023 (2005)

24) Roennefahrt, K. W.: Nitrate elimination with heterotrophic aquatic microorganisms in fixed bed reactors with buoyant carriers, Aqua, 5, 283-285 (1989)

25) Szekeres, S., Kiss, I., bejerano, T. T., and Soares, M. Z. M.: Hydrogen-dependent denitrification in a two-reactor bioelectrochemical system, Wat. Res., 35, 715-719 (2001)

26) Kim, Y.S., Nakano, K., Lee, T.J., Kanchanatawee, S., and Matsumura, M.: Onsite nitrate removal of groundwater by an immobilized psychrophilic denitrifier 
using soluble starch as a carbon source. $J$. of Biosci. and Bioeng., 93, 303-308 (2002)

27) Kesseru, P., Kiss, I., Bihari, Z., and Polyak, B.: Investigation of the denitrification activity of immobilized Pseudomonas butanovora cells in the presence of different organic substrates, Wat. Res., 36, 1565-1571 (2002)

28) Mohseni-Bandpi, A. and Elliott, D., J.: Groundwater denitrification with alternative carbon sources, Wat. Sci. Tech., 38, 237-243 (1998)

29) General information on nitrogen: http:// www.frwa.net/TRAINING/WASTEWATE R/general_information_on_nitrogen\%20A. htm

30) Burrell, P. C., Phalen, C. M., and Hovanec, T. A.: Identification of bacteria responsible for ammonia oxidation in freshwater aquaria, Appl. Environ. Microbiol. 67, 5791-800 (2001)

31) Metcalf and Eddy, Inc: Wastewater Engineering: Treatment disposal reuse, U. S. Environmental Protection Agency, Washington, DC, 696-716 (1979)

32) Nuhoglu, A., Pekdemir, T., Yildiz, E., Keskinler, B., and Akay, G.: Drinking water denitrification by a membrane bio-reactor, Wat. Res., 36, 1155-1166 (2002)

(Submitted 2005. 12. 16)

(Accepted 2006. 3. 17) 